-

\title{
Sustainability and Sustainability Marketing in Competing for the Title of European Capital of Culture
}

\author{
Valentina BURKSIENE, Jaroslav DVORAK, Gabriele BURBULYTE-TSISKARISHVILI \\ Klaipeda University, Department of Public Administration and Social Geography, Klaipeda, Lithuania \\ v.burksiene@gmail.com, jaroslav.dvorak@ku.It, gabriele.burbulyte@gmail.com
}

\begin{abstract}
Background and Purpose: An analysis of the dimension of sustainability in the context of competing for the title of the European Capital of Culture $(\mathrm{ECOC})$ is included in the article. The authors of the research agree that the proper integration of cultural policy into the social system impacts and changes cultural values and beliefs, shifting them towards sustainable behaviour and sustainability. Many authors analyse the interrelation between culture and sustainability, thus defining the role of culture for sustainability. However, few discuss possible approaches or tools, which may offer assistance in the matter of how to reach sustainability in the context of culture.

Design/ Methodology/ Approach: Research is based on the comparative analysis of the applications of the respective cities. The TBL methodology is implemented using the content analysis method as a tool. The outcomes of the content analysis are then used for the elaboration of the qualitative multi-attribute model using the DEX methodology. Results: While analysing bidding documents for the ECoC we: a) define the importance of the marketing plan (described as a comprehensive action) and b) argue that ECoC marketing needs to be turned to "sustainability marketing" as it is described and defined by many authors.

Conclusions: The ECoC Commission should consider the importance of culture for sustainable development and, respectively, should evaluate the marketing plan of applicants under the sustainability framework.
\end{abstract}

Keywords: culture; European Capital of Culture; marketing; sustainability; sustainability marketing

\section{Introduction}

Culture undoubtedly affects sustainable development, as has been acknowledged by many authors (Hawkes, 2001; Nurse, 2006; Fithian and Powell 2009; Maraña, 2010; Scammon, 2012; Sazonova, 2014; Immler and Sakkers, 2014; Dessein, Soini, Fairclough and Horlings, 2015). Moreover, culture could be treated as a key element for the concept of sustainable development (Opuku, 2015), capable of linking different areas of policy (Dessein et al., 2015). The European Union, for this reason, developed the Programme of The European Capital of Culture (ECoC, hereafter - the Programme) which is arguably one of the most successful of all cultural projects (Lamza - Maronic et. al, 2011). It is strongly believed that the ECoC initiative significantly maximises social and economic benefits, especially when the events are embedded as part of a long- term culture-based development strategy of the city and the surrounding region.

The integration of cultural activities of the Programme should develop links between different domains (e.g. culture, education, tourism, territorial planning, social services, etc.) and help to build sustainable partnerships with economic and social sectors. According to Dessein et al. (2015, p.44) "culture is a key factor in the adaptation and learning new practices". Chiu et al. (2010) state that people act on the beliefs and values they perceive to be widespread in their culture.

Marketing, therefore, appears to play a not insignificant role in the competition for the title, while there is a requirement pertaining to the integration of the $E C o C$ project into the common strategic plan of the city and of its appropriate marketing. As Van Aalst and. Van Melik (2012) note, municipalities look for the opportunity to

Received: July 4, 2017; revised: October 13, 2017; accepted: January 10, 2018 
implement mega-events. Despite the fact that marketing is defined as an obligatory action for the $E C o C$ project and that marketing costs should be planned in the budget and approved by the awarding Commission, Lamza-Maronić et al. (2011) have revealed the huge discrepancy in the marketing budgets of the respective candidate cities, as well as the means/tools of promotion [advertising]. In this way, city governments compete in the performance of their duties and provide public value for citizens. Appropriate marketing facilitates communication of the $\mathrm{ECoC}$, not only during the designated year but in the preparatory period as well. Marketing success relates to the choice of the appropriate audience.

If culture is perceived to be so important for sustainable development, why then could marketing not be the means of spreading the idea of sustainability within a particular society or even shifting (transforming) that society towards the sustainability paradigm? The role of social marketing in changing individual or societal values, beliefs and behaviour has been defined by authors such as Thaler and Helmig (2013), Senkus (2013), Pykett et al. (2014), and Wróblewski (2016) among others. The marketing strategy of the $E C o C$, thus, should also include social or even sustainability aspects (complex interlinks between social, environmental/ecological and economic dimensions). Sustainability marketing criteria, however, are still missing from the current applications and reports and are thus the main focus of this article.

We argue that the variety of applied marketing approaches for the management and implementation of such a complex event as the ECoC should consider sustainability marketing as it is defined by Belz and Karstens (2005), Peattie and Belz (2010), Nkamnebe (2011), Rakic and Rakic (2015), Lim (2016) and others. The requirement for sustainability marketing should be added to the criteria by the respective Commission of the ECoC and evaluated while choosing the winner. Marketing tools that could foster any city's sustainability should compulsorily be planned in the preparation period and displayed in the application (bidding) forms of the candidate cities.

Sustainability, according to complexity theory, is defined as a complex system (Peter and Swilling, 2014). Sustainability marketing as a process includes economic, environmental, social, ethical, and technological dimensions (Lim, 2016) proving its complexity as well. This allows one to argue that marketing in terms of the ECoC should be based on and evaluated using the Triple Bottom Line approach (TRB, further - the Approach). The Approach is explained in detail by numerous authors, starting with John Elkington in his 1997 book "Cannibals With Forks: The Triple Bottom Line of 21 st Century Business"1.

The case of Lithuania has been chosen to provide the context for an analysis of the problem. The synergetic effect of culture and tourism plays a crucial role, both for economic growth and labour market development. Cultural tourism not only helps to protect cultural heritage, but also opens new prospects for collaboration among different sectors, creates attractive tourism products, and stimulates innovations (see Aubert et al., 2005). This is the reason why cultural tourism is distinguished as one of the primary spheres of Lithuania's development. Furthermore, a special measure dedicated to the protection of cultural heritage was funded by European Structural Funds in the period of 2007-2013. During the current EU structural funding period of 2014-2020, additional measures are planned resulting in the creation of cultural tourism routes and the promotion of the country's cultural tourism at an international level. Digital marketing is among the most funded priorities. However, the economic benefits of culture in Lithuania were not recognised by the Government until 2007 (Rindzevičiūtè et al., 2016) ${ }^{2}$. Vilnius, the capital of Lithuania, became the first Lithuanian city awarded the $E C o C$ title in 2009. An analysis (Nechita, 2015, p. 105) reveals that no Lithuanian cities had bid for the title of $E C o C$ in the period of 2013-2019.

\section{Cohesion of Culture, Marketing and Sustainability}

Culture, according to Opuku (2015), could be treated as a key element for the sustainable development concept, while it is the bond capable of linking people's consciousness towards the built-up and the natural environment. Culture (in particular evolutionary culture) empowers people with the ability to understand the common world and its problems afresh. Culture can be considered as a sphere where individual and collective meanings are created with sustainable development as a core value (Sazonova, 2014). As the authors agree that sustainable development requires a holistic attitude and a systemic way of thinking, culture thus becomes an indispensable tool for integrating new values and new modes of life, a novel pathway for the development of economics. Moreover, authors depict culture as the core of the new paradigm of sustainable development and sustainability.

Soini and Dessein (2016) discussed the roles of culture in relation to sustainability and offered three framing representations of culture and sustainability (see Fig. 1). The three light circles represent three traditional sustainability pillars (social, economic and ecological) while the darkgrey circle represents culture. The first mode considers culture as if it were the fourth pillar of sustainability. The second mode refers to culture playing a mediating role in order to achieve economic, social, and ecological sustain-

$1 \mathrm{https}$ :/www.mindtools.com/pages/article/newSTR_79.htm

2 That year the Minister of Culture approved the Strategy for the Promotion and Development of Creative Industries. 


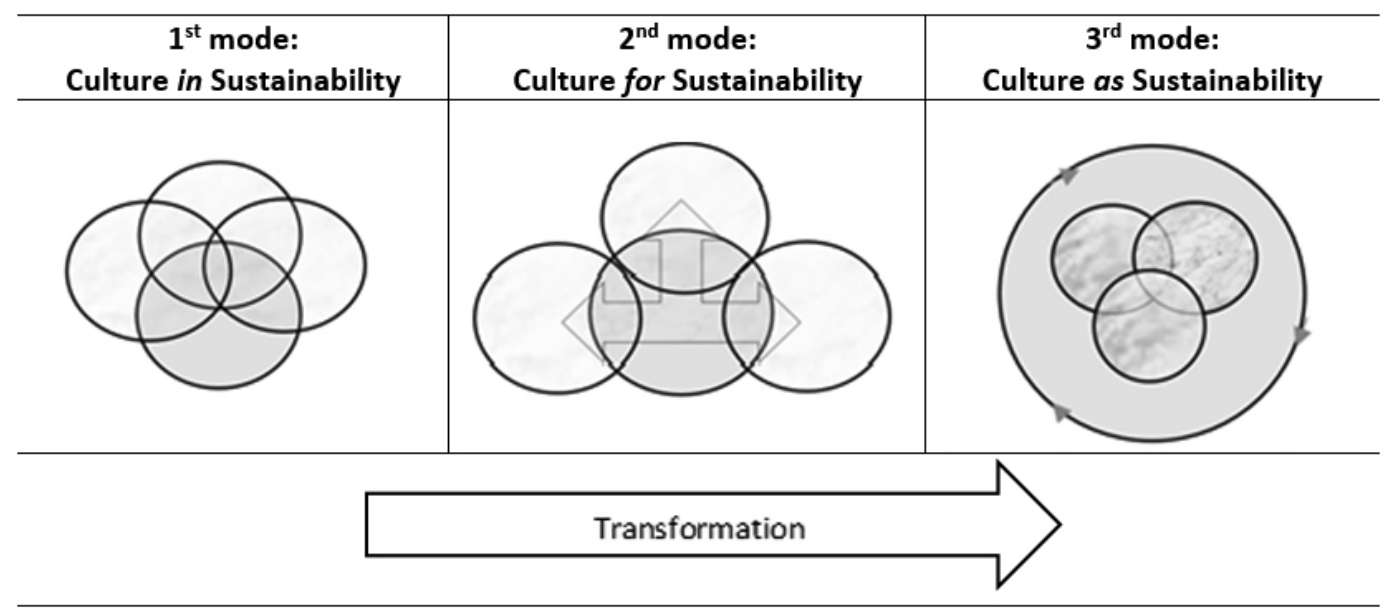

Figure 1: Shifting modes of culture - sustainability relations. Adapted from: Soini and Dessein (2016, p.6)

ability. The third mode considers culture as a necessary foundation for meeting the overall aims of sustainability. In other words, culture is "a part of a constantly evolving process aiming for transformation" (Soini and Dessein, 2016, p. 9).

According to Soini and Dessein (2016), moving from the first to the second and to the third mode is a must for the complex shift to sustainability. The ideal result of this shift would lead to: a) the shaped or reshaped meaning of nature, considering it as a constituent of culture; b) completely new policies that intrinsically accommodate sustainability principles; c) new modes of self-governance or even meta-governance. While addressing the direction of the transformation to sustainability and defining the relationship between culture and sustainability in eight dimensions, Soini and Dessein (2016) neither try to give an answer to the question of how to undertake transformation, nor provide the tools to do so.

Eroglu and Picak (2011), Greblikaite et al. (2016) provide a reminder that culture is perceived as a set of shared beliefs, values, models of conduct, rules of coexistence and expected behaviours. Sustainability is also related to beliefs, values and behaviours (Bell and Morse, 2003; Senge and Smith, 2008; Epstein, 2008; Edwards, 2009; Sazonova, 2014; Giltrow, 2015). Eroglu and Picak (2011, p.146) state "deeply embedded and irrational shared values shape political institutions as well as social and technical systems, all of which simultaneously reflect and reinforce values and beliefs". While sharing the above view, we further argue that the impact of political decisions and actions is of crucial importance for sustainable development. Local and regional cultural policy can foster societal shifts towards sustainable behaviour, the participation of citizens and sustainable collective actions, or can even contribute to the transformation into a sustainable society. Cultural space is suitable for dialogues, creative approaches and diversity. It allows new viewpoints for development and prevents sustainability from "a frozen lifeless doctrine" (Sazonova, 2014, p. 7).

Agreeing with scientists such as Thaler and Helmig, (2013), Senkus (2013), Pykett et al. (2014), and Wróblewski (2016), we state that social marketing is a very helpful approach for changing the values or behaviour of society. While the new mode - sustainability marketing - has evolved since the beginning of the $21^{\text {st }}$ century, we argue that this type of marketing might be a useful tool for transformation to sustainability in the framework of culture policy. Social marketing is included in sustainability marketing as it represents a social dimension. Ecological / environmental / green marketing (see in Belz and Karstens, 2005; Peattie and Belz, 2010; Nkamnebe, 2011; Rakic and Rakic, 2015; Lim, 2016) represents the environmental dimension, and business marketing represents the economic dimension.

Sustainability marketing today is not something new or unknown to marketing experts. As with other research areas, marketing has developed while reacting to the sustainability issues which have emerged. This process has been defined, researched and analysed by many authors (see Belz and Karstens, 2005; Peattie and Belz, 2010; Nkamnebe, 2011; Rakic and Rakic, 2015; Lim, 2016). Sustainability marketing requires innovative (systemic) thinking of marketing managers and a long-term orientation (Peattie and Belz, 2010). According to Rakic and Rakic (2015), sustainability marketing is oriented towards the whole community, its social goals and the protection of the environment. It requires the engagement of national and local governments, organisations and population as well as the necessary capital (human, financial, infrastructural, etc.). A set of characteristics is related to sustainability marketing including economic, environmental, social, ethical, and technological dimensions (Lim, 2016) as well 
as transformation potential of marketing activities (Peattie and Belz, 2010).

The above concepts need to be employed in practice by local, regional or national governments while announcing sustainability goals. We argue that the EU's interdisciplinary initiative of the $E C o C$, which integrates all three conceptual aspects (i.e. culture, sustainability and marketing), could play a significant role in fostering the idea of sustainability with more significant power.

\section{The European Capital of Culture Programme}

The political initiative of the $E C o C$ has evolved greatly since its beginnings in 1985. It is strongly believed that the $E C o C$ significantly maximises social and economic benefits, especially when the events are embedded as a part of a long-term culture-based development strategy of the city and the surrounding region.

The integration of the Programme into long-term city strategy is encouraged, as it has a sustainable impact on local economic, cultural and social development (Turşie, 2015). Therefore, most cities already emphasise longterm cultural, social and economic impact while bidding for the $E C o C$ title (Nechita, 2015). The integration of the Programme into long-term strategies, furthermore, might foster polycentric spatial development involving peripheral (rural or former urban) areas around the bidding city and make them (and thus the entire area) more attractive for business investments, new inhabitants and tourists (Nemeth, 2010).

The real and responsible integration of the Programme in an overall development strategy could, according to Richards (2000, p.12), serve as a guard "against the development of 'festivalisation' which threatens their cultural sustainability". This Programme, with its obligatory means of marketing, might also be perceived as a perfect outlet for the integration of different (complex) sustainability aspects into the development of the city.

Indeed, the value chain of cultural events with further commercialisation (e.g. Consumer city (Glaeser et al., 2001)) creates positive economic outcomes (for income and employment), but also meets with opposition (van Aalst and van Melik, 2012). There are authors (Aubert et al., 2015; Nechita, 2015; Draghici at al., 2015; Steiner et al., 2015) who emphasise several negative aspects or difficulties, such as the underestimation of costs and the overestimation of possible benefits; fewer comprehensive changes; difficulties in measuring the economic and social impact, the lack of long-term sustainability projects; a lack of finance to support the new cultural infrastructure both following the year of the $E C O C$ and later from a long-term perspective; the negative effect on the wellbeing of the regional population, etc.
As announced by the Commission responsible for such matters (Commission staff working document, 2012): "the European Union has a moral and legal obligation to take action to promote and safeguard cultural diversity", especially since the UNESCO Convention on the Protection and Promotion of the Diversity of Cultural Expressions came into force in 2007. All planned cultural events must reflect contemporary life, emphasising the unique culture and cultural heritage of the city. Each year two cities from the Member States are chosen to hold the title. According to Herrero et al. (2006), Boland (2010), Lamza-Maronić et al. (2011) and O'Callaghan (2012), the title awarded to the city creates the conditions for raising the international profile of a city; implementing programmes for cultural activities and art events; long-term cultural development; strengthening communications in the city; attracting domestic and foreign tourists; enhancing feelings of belonging and self-confidence; the growth and expansion of the local cultural audience; creating a festive atmosphere and new cultural facilities; urban redesign; and the regeneration, rebranding and repositioning of the city. The title, furthermore, may help with drawing "a new development path" if "struggling with an economic, social and identity crisis" (Aubert et al., 2015, p. 27) as well as the transformation of "the local population from the consumers of the city into creators of the city" (ibid, p. 28) or a shift to the concept of culture-led regeneration, which is stimulated by young organisers and entrepreneurs (Hudec and Džupka, 2016).

These obvious benefits (both economic and social) explain such a fierce battle for the title, for which the young democracies of the post-Soviet countries are also eager to bid. We see, therefore, Poland, Estonia, Romania, Slovakia, Bulgaria, Croatia, Hungary, and Lithuania (a total of 10 young democracy countries from 28 candidates overall in the period of $2020-2033$ ) in the list of ECoC candidate countries (Lamza-Maronić et al., 2011). The "Melina Mercouri Prize" of 1.5 million Euro awarded by the Commission seems to be quite an attractive incentive for these countries.

\section{$4 \mathrm{ECoC}$ regulation analysis}

Sustainability requirements and progress evaluation An analysis of the $E C o C$ documents (application forms, studies and reports) reveal that the requirement of sustainability had not been included in primary documentation. Palmer's report (Palmer/Rae Associates, 2004) states that local initiatives were more sustainable than those attracting large audiences, and most projects from the reporting period (1995-2004) are not sustainable over time. Respondents emphasised that, despite the huge levels of investment and activity, they rarely seem to have been matched by longterm development. The ECoC had not been part of a sustainable strategy for the city. Therefore, the advice arising 
out of the Report includes recommendations to distinguish between short-term and longer-term impacts, to recognise the implications of approaches for maintaining sustainable initiatives, and to create sustainable programmes.

As a result, the Creative Europe Programme, which has replaced the above-mentioned Programme recently, already pays special attention to promoting smart, sustainable and inclusive growth while promoting European cultural diversity. Sustainability is considered to be a prerequisite for the new selection criteria. Applications from candidate cities need to be embedded in a long-term strategy for cultural development, and to include plans for building sustainable partnerships with the economic and social sectors (Commission staff working document, 2012).

The Guide for cities preparing to bid for the ECoC title in the period of $2020-2033$ draws attention to the fact that successful $E C o C$ s have used the title for general development producing sustainable cultural, social and economic impact. They embedded the programme's activities into the city's overall strategy, developing links between culture, education, tourism, territorial planning, social services, etc. (European Capitals of Culture, 2014). The potential candidates, therefore, are asked to show their cultural and city strategy in their bid-books as well as to have broad and strong political support and a sustainable commitment from the local, regional and national authorities (European Capitals of Culture, ibid, p. 11).

\section{Marketing requirements and evaluation of progress}

An analysis of the primary $E C o C$ programme documents (the application form, studies and reports) show that despite the fact that there were no strict requirements for marketing the $E C o C$ programme, "most of the host cities made considerable investment in marketing" (Palmer/Rae Associates, 2004, p. 128). The study by Garcia and Cox (2013) revealed that marketing strategies currently look more sophisticated and are usually treated as a priority which is supported by a significant part of the total budget.

However, the Palmer Report (Palmer/Rae Associates, 2004) states that cultural events were mostly not interrelated and, therefore, promoted separately as isolated events. This fragmentation of the cultural programme led to the lack of overall understanding of the programme in many ECoCs, which is why some respondents emphasised the importance of assigning more money to overall complex marketing, perceiving it (together with communication) as one of the priorities in the ECoC. No word of marketing regulation, however, is mentioned in the Commission staff working document of 2012 (Commission staff working document, 2012).

Some key inscriptions concerning marketing occur in the common Guide for cities preparing to bid (European Capitals of Culture, 2014, p. 22). Marketing and communication is perceived here as a key function, which seems to be treated as increasing online activity. The role of in- forming wide audiences about $\mathrm{ECoC}$ as a comprehensive action of the Union is also seemingly allocated to marketing. However, it is followed by the only requirement noted - namely that "The marketing and communication of the ECOC give due prominence to the ECOC as a European Union action" (European Capitals of Culture, 2014, p. $23)$. Working relationships between the $E C o C$ team and the marketing and tourism departments of the city are required. However, not a single word can be found on sustainability or sustainability marketing.

As already mentioned in this paper, marketing should comprise means which target both visitors and locals. While describing the outreach (European Capitals of Culture, 2014, p. 12), the Guide emphasises sustainability as a requirement or condition for the creation of new and sustainable opportunities for all citizens to be involved and attend cultural activities. Furthermore, the overall strategy for audience development, with links to education and schools' participation, is obligatory for applicants. The authors of this study argue that better conditions for sustainability marketing could hardly be found. All that is undoubtedly needed is to have a sustainability marketing orientation, which is common for sustainability marketing experts but usually unfamiliar to those who are responsible for bidding and implementing the $E \mathrm{CoC}$ programme.

\section{Methods and procedures}

Selection of the ECoC applications. For research purposes, the two candidate cities for the title of ECoC 2022 (Kaunas and Klaipeda) were chosen according to the following criteria:

- the former post-Soviet industrial cities are in transition, meaning that some developmental components are disappearing, paving the way for new ones;

- Lithuania's sustainable development strategy was renewed in 2009, meaning that the authorities of both cities should take care of the strategy's implementation issues;

- sustainable public finance of candidate cities for the ECoC title;

- both cities have experience in the coordination and sound organisation of big annual international events (e.g., Kaunas Jazz festival, Klaipeda Jazz festival, Klaipeda Sea festival, or Hansa days in Kaunas).

Vilnius, the capital of Lithuania, was awarded the title in 2009. In July 2015, six Lithuanian cities (Anykščiai, Jonava, Kaunas, Klaipèda, Plungè, and Rokiškis) submitted applications for the first stage. Finally, two cities - Kaunas (the $2^{\text {nd }}$ largest city) and Klaipeda (the $3^{\text {rd }}$ largest city) competed for the title (Figure 2). Kaunas was chosen as most suitable for the award and will hold the title of the cultural capital of Europe in 2022.

National political support for the $E C o C$ was provid- 
ed through taking a decision at the national level on the amount of the financial contribution up to 50 percent of the programme budget (not exceeding 10 million euros, with no capital investment). Politicians from the Kaunas city and Kaunas district municipalities agreed on the programme budget of 16 million euros in total (12 million and 4 million euros, respectively). As for the Klaipèda city application, the three cities decided to allocate almost 16 million euros (the three cities of Klaipeda, Palanga, and Neringa sharing, respectively, 15 million, 700,000 and 243,000 euros). While the above figures show a similar contribution from the respective municipal budgets, the total amount for the overall implementation of the Programme, however, is not equally allocated (see Fig. 2).

Klaipeda planned to attract more funding from sponsors. From the previous title-winners' experience, this part of the budget usually ranges from $8 \%$ to $28 \%$ of the total budget (Milton Keynes Council, 2015).

Research methodology is based on the comparative analysis of the applications of the respective cities. The budgets of both candidate cities are compared, aiming to emphasise political attitudes to the $E C o C$ and its marketing.

The category of culture is not included in the research as we agree with Sazonova (2014) and Soini and Dessein (2016) who consider culture as the foundation, basis or "space" for meeting the overall aims of sustainability. The category of politics is also excluded because the initiative of the $E C o C$ itself is political in its origins. The political aspect is a must according to the rules of the Programme.

For the implementation of comparative research, the Triple Bottom Line (TBL) methodology is used as the methodological foundation. The TBL is usually "used for measuring performance in relation to economic, social and environmental parameters" (Golob et al., 2015, p. 73). Research into sustainability and sustainability marketing (as these are systemic in their origins) can easily proceed while using the TBL methodology ${ }^{3}$ as the latter is based on the interrelation between the three main sustainability dimensions: social, ecological/environmental and economic, also defined as the "3P", i.e. People, Planet, Profit.

The TBL methodology is implemented using the content analysis method as a tool. The classical version of the content analysis is used while calculating the core words (sustainability, ecology, marketing, sustainability marketing) and analysing the context of the usage of sustainability and sustainability marketing. The following research structure is applied:

statements with the words sustainable and sustainability are counted and compared excluding the template phrases;

phrases related to sustainability aspects based on the " $3 \mathrm{P}$ " categories are analysed, aiming to express and compare balance among all three dimensions of sustainability in both applications, including the category of sustainability as well. Specific subcategories have been chosen to count under each of the P's (see Table 1).

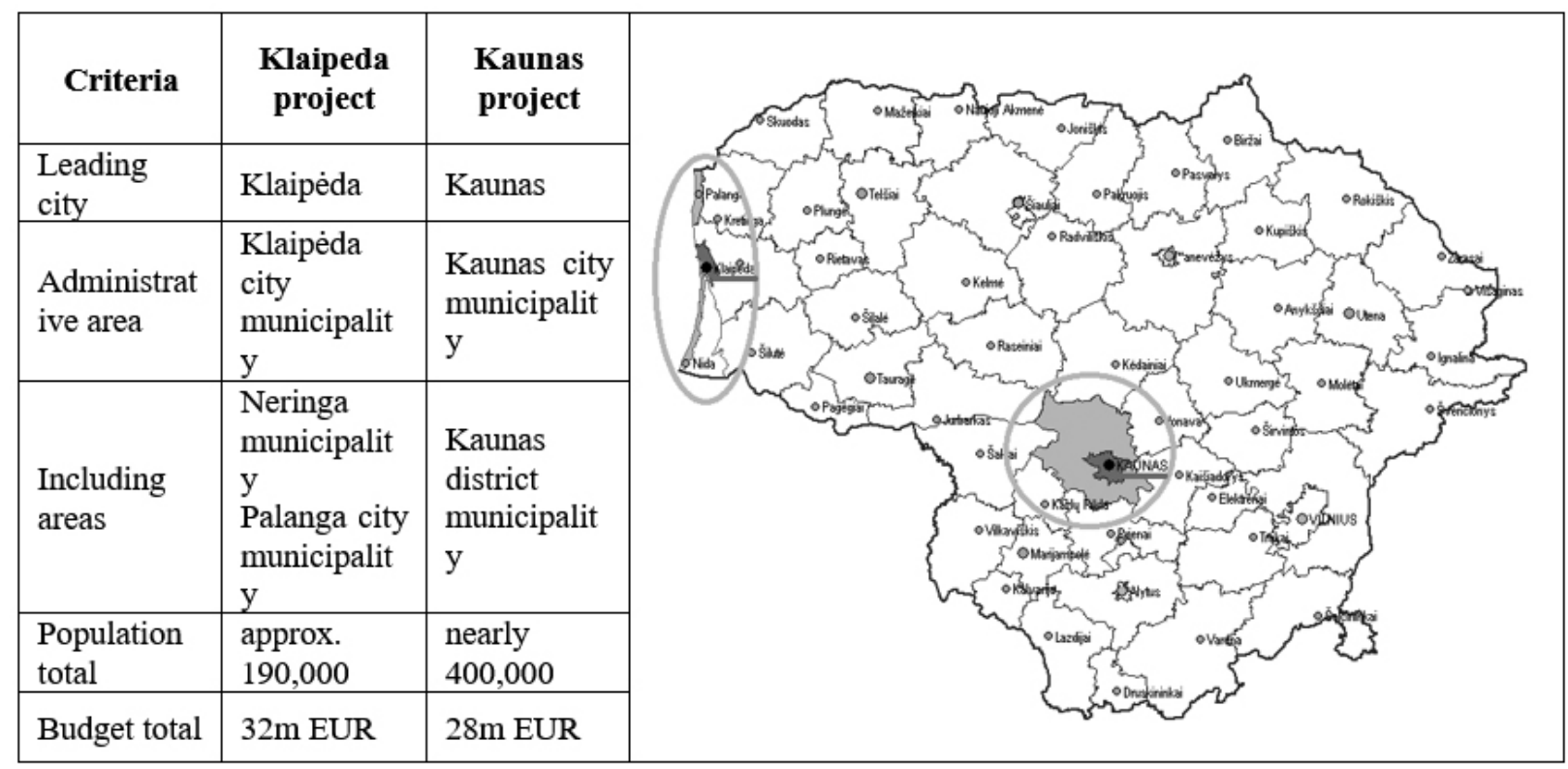

Figure 2. Lithuanian candidate cities for the ECoC 2022

3 https://www.mindtools.com/pages/article/newSTR 79.htm; https://link.springer.com/article/10.1007/s13520-012-0019-3\#Sec3 
Table 1: Dimensions for analysis (own elaboration)

\begin{tabular}{ccc}
\hline Sustainability dimension & Category & Subcategory \\
\hline Social & People & $\begin{array}{c}\text { society, community, residents, citizens, youth, women, } \\
\text { grandparents, children, etc. }\end{array}$ \\
\hline Environmental (ecological) & Planet & $\begin{array}{c}\text { ecology, ecosystem, nature, natural environment, } \\
\text { landscape, etc. }\end{array}$ \\
\hline Economic & Profit & $\begin{array}{c}\text { industry, industrial environment, economics, tourism, } \\
\text { visitors, hospitality, employees, employers, etc. }\end{array}$ \\
\hline & Sustainability & \\
\hline
\end{tabular}

Table 2: Three-grade scale for assessment of an appropriate sub-attribute (own elaboration)

\begin{tabular}{c|c}
\hline Score & Value \\
\hline $0-3$ & low \\
\hline $4-6$ & medium \\
\hline $7-10$ & high \\
\hline
\end{tabular}

The calculation of the categories and subcategories is implemented using the ATLAS.ti software programme (the programme calculates and displays the amount of each single word in both applications; all the words (subcategories) related to every $\mathrm{P}$ are chosen subjectively by the authors). The results of the calculation are displayed and compared in the radar diagram.

The outcomes (data) of the content analysis are then used for the elaboration of the qualitative multi-attribute model using the DEX methodology. The model of sustainability marketing is based on theoretical definitions of the subject and following the recommendations of the DEX methodology as proposed by Bohanec (2015) and Golob et al. (2015). For this purpose, a primary hierarchical model of sustainable marketing (as a helpful tool for the decision-makers in the awarding procedure) is elaborated.

The model is based on qualitative variables while choosing a core attribute, basic and aggregated sub-attributes, and is tested for the evaluation of the marketing sections of the analysed applications. The three-grade scale is applied for the assessment of the presence of an appropriate sub-attribute or its equivalent (congruent in meaning). Due to the limited inscriptions (the largest number of statements in a single sub-attribute does not exceed 10) we chose to use a scale from 0 to 10 (as described in Table 2).

The model is developed using the DEXi software programme. The results are compared while displayed in the evaluation table that is composed using DEXi modelling.

Although TBL methodology allows organisations to rearrange their activities in a sustainable manner, there are some difficulties in measuring the impact they have on the social environment and nature (Slaper and Hall, 2011). TBL methodology has several limitations (Sridhar and Jones, 2013):
- social and environmental performance is unique in every situation and is difficult to quantify;

- it lacks the ability to aggregate the results across the three principles of TBL;

- the three separate accounts cannot easily be added up. It is difficult to measure the planet and the people in the same terms as the profits;

- it is more useful for business organisations.

An analysis with DEX methodology and the DEX-I programme also led to some limitations. The modelling of basic and aggregated attributes is limited to three as "too many descendants cause a combinatorial explosion on the size of corresponding utility functions" (Bohanec, 2015, p. 14). Therefore, the hierarchical model of sustainability marketing is based on the most important attributes (in our subjective understanding and choice). The limited options in the scale menu and recommendations such as "use the least number of values $\langle\ldots\rangle$ two to four" limited the development of the sustainability marketing model as well.

\section{Results}

While analysing the applications of the candidates, it appeared that candidates have different goals while acting as the $E C o C$ and implementing the associated cultural programmes. Kaunas treats the ability to create a unifying identity and to become a contemporary capital as the main goals, while Klaipeda, on the other hand, recognises itself as a province and wishes to return life to the city via cultural events. Both candidates mostly emphasise the social dimension and cultural needs for society.

Different models of initiation of the $E C o C$ have been 
copied by candidate cities year-by-year (Herrero et al., 2006). The previous experience of some other candidate cities (for instance, Cardiff) have shown that the rationale to take part in the competition is exclusively connected with marketing and born in the marketing department of the city (Griffiths, 2006). Kaunas' initiative to bid for the $E C o C$ title, however, started from a group of various independent representatives. The group applied to the Kaunas city council and received unanimous support from the very beginning. As for the city of Klaipeda, the initiative for seeking the $E C o C$ title had already been included in the "City Strategic Action Plan for 2013 - 2020". This imperative for successful participation has been used in the case of Liverpool, where local strategies were linked to the ECoC competition (Griffiths, 2006). The consistent orientation of the city of Klaipeda towards this may be proved by the fact that Klaipeda won the title of the Lithuanian Capital of Culture in 2017.

Despite the different origins of the initiative, both cities provided clarification of the Programme inclusion in their long-term strategies. We argue, therefore, that close cohesion between the $E C o C$ programme and the sustainability approaches would occur if any of the latter were strategically planned. A deeper analysis of the respective documents, however, revealed somewhat weak integration of sustainability and its marketing approaches into the Programmes (see Table 3).

The results of the analysis that are presented in the $3^{\text {rd }}$ table enable us to affirm that the attitude of the candidate cities towards marketing differs markedly. Even though both cities have planned various means of marketing reflecting all seven groups, the analysis of the marketing spectrum revealed that Klaipeda has described the more detailed and more accurate marketing strategy. These findings raise the question: what affected the different choice of the two cities? The explanation could be that Klaipeda, as the third city in Lithuania, undoubtedly needs to search for an exceptional competitive advantage; nonetheless, the influence of the ruling party's ideology could be felt as well (due to the long-term political governance of the liberal party, citizens are treated or even valued as consumers).

Comparative analysis revealed most inscriptions to be similar (e.g., bilingual websites, virtual platforms, computer games, outdoor stands, logos on transport vehicles, etc.). Both cities, however, offered some different marketing means (e.g., Kaunas: marketing via sport, flying balloons, a hedonometer for evaluation, and word of mouth; Klaipeda: exposition of national costumes, post cards, post stamps, cultural passport, SMS, and meeting points). It becomes obvious while analysing the respective proposals that Klaipeda's marketing strategy includes more traditional means than Kaunas, which mostly opted for digital capabilities, thus fulfilling the requirements of the Guide (European Capitals of Culture, 2014).

The huge variety in terms of marketing means would be highly beneficial for sustainability marketing, if only such requirements were included in the Programme Guide or sustainability as an aim were seriously considered in the cities' strategies. The results of the content analysis enable us to state that neither one nor the other exist de jure. Moreover, in terms of the previously discussed context, we see that none of the applicants even attempted to change the perception (i.e. brand) of the city as with Liverpool (Boland, 2010) and/or to market the city as Lithuania's centre of culture, which could increase the country's international competitiveness.

The content analysis revealed the emphasis to be on People (i.e. the social aspect) in both applications. This category covers around 600 words (e.g. society, community, citizens, residents, youth, etc.). Conversely, there is close to zero mention of Planet (i.e. the environmental or ecological aspect) and the category of sustainability. The scale (see Fig. 3) reveals that division among the categories looks very similar in both applications, with the greatest focus on People. Despite several questions dedicated to sustainability (Application template questions No. 5, 7, 17, 20 and 47) the category of sustainability is reflected

Table 3: Comparison of Kaunas and Klaipeda bid details (own elaboration)

\begin{tabular}{|c|c|c|}
\hline Category & Kaunas & Klaipeda \\
\hline \multicolumn{3}{|c|}{ Marketing } \\
\hline Promotion and Marketing budget & $6 \mathrm{~m}$ Eur $(20 \%$ of total budget $)$ & $4 \mathrm{~m}$ Eur ( $12.5 \%$ of total budget) \\
\hline Marketing means & All groups4 (22 positions) & All groups (30 positions) \\
\hline "Marketing" term used & 36 & 19 \\
\hline \multicolumn{3}{|c|}{ Sustainability } \\
\hline "Sustainability" term used & 8 & 5 \\
\hline "Ecology" term used & 3 & 7 \\
\hline
\end{tabular}

4 Printed materials and broadcasting; new technologies and new media; trade; special events; other initiatives revealed by M. Lamza-Maronić, et al. (2011) 


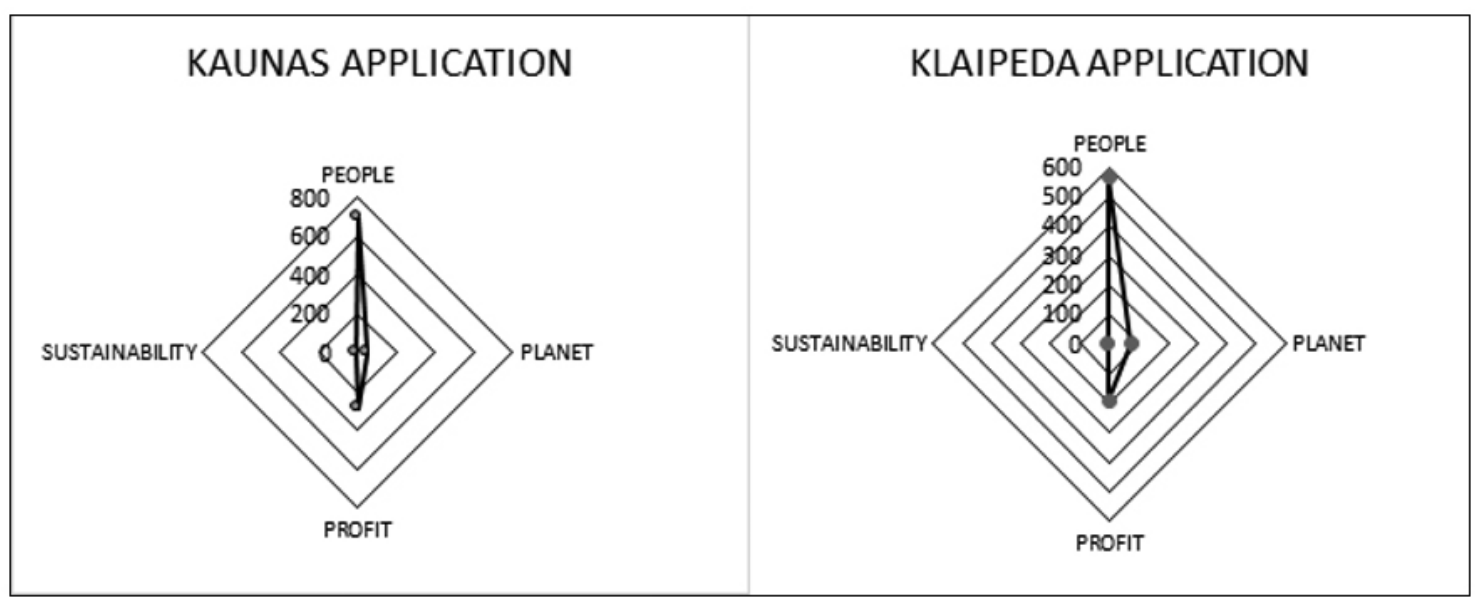

Figure 3: Sustainability dimensions in Kaunas' and Klaipeda's applications for the title of ECoC (own elaboration)

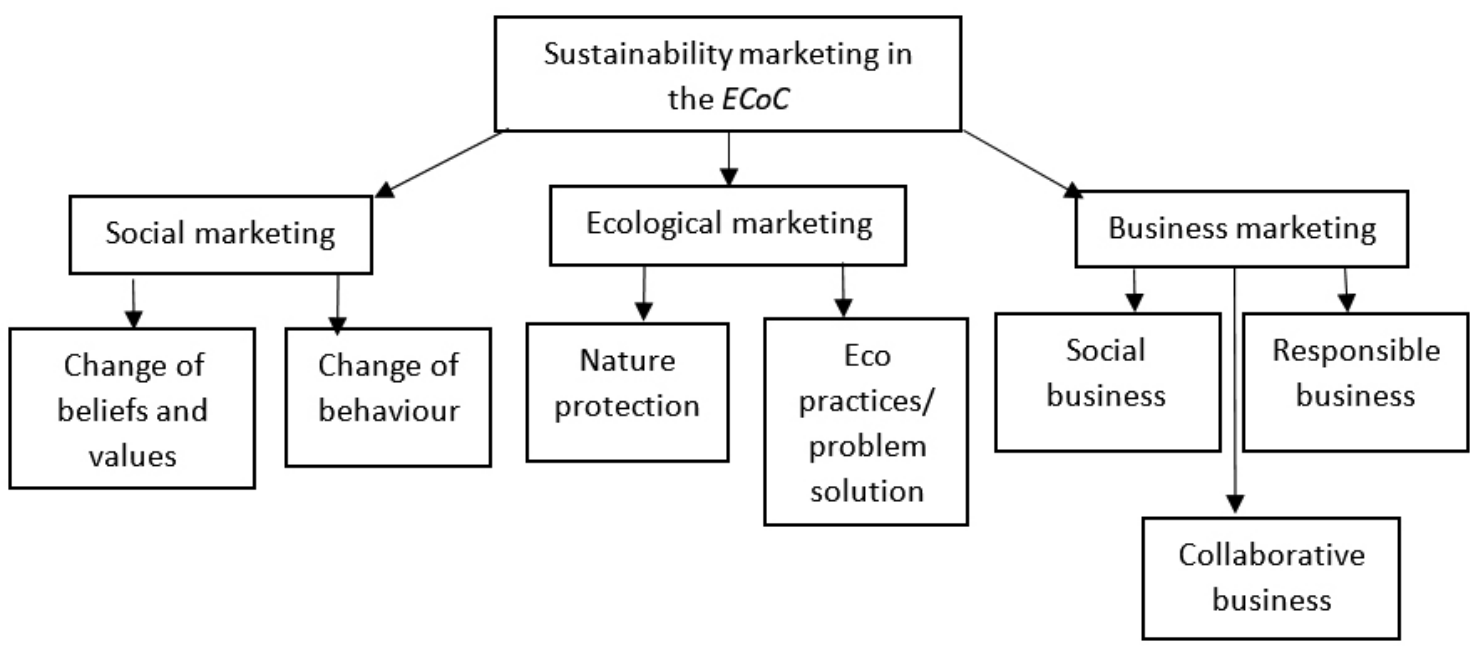

Figure 4. Model of sustainability marketing (own elaboration)

very poorly. The same is true of Planet.

Agreeing with the definition of sustainability marketing and following the recommendations of the DEX methodology (as proposed by Bohanec, 2015) we developed a primary hierarchical model of sustainable marketing that could serve as a helpful tool for decision-makers while choosing the winner of the $E C o C$ title (see Fig. 4).

Sustainability marketing is a core attribute in the model and represents the main output. The lowest or basic attributes represent inputs of the actions, while the intermediate attributes (the aggregated ones) represent intermediate results. In reality, the model could be further developed involving different decision-makers or their groups that have different and sometimes even conflicting goals (see, e.g., Bohanec, 2015).

Furthermore, the model has been tested by evaluating the marketing sections of the analysed applications. The results of the evaluation (calculated using the DEXi software programme) are presented in Table 4.

According the results of the evaluation, it is evident that the marketing section of the Kaunas application refers slightly more to sustainability than the corresponding section of the Klaipeda application. Despite the better position of social marketing, the other two equally important parts of the marketing section (i.e. environmental marketing and business marketing) are equally poorly expressed in the applications.

The results of the overall research, therefore, lead to the conclusion that sustainability marketing is misused in both applications. 
Table 4: Sustainability marketing aspects in Kaunas' and Klaipeda's applications (marketing sections) (own elaboration)

\begin{tabular}{c|c|c}
\hline Klaipeda & Option & Kaunas \\
\hline LOW & SUSTAINABILITY MARKETING & MEDIUM \\
\hline Low & Social Marketing & medium \\
\hline low & Believes and values & medium \\
\hline low & Behaviour & Low \\
\hline Low & Environmental Marketing & low \\
\hline low & Nature protection & Medium \\
\hline low & Eco practices & low \\
\hline Medium & Business Marketing & low \\
\hline low & Social business & high \\
\hline low & Responsible business & Collaborative business \\
\hline high & &
\end{tabular}

\section{Discussion}

Despite the fact that authors assign different models of relations between culture and sustainability, it has already been proven that culture plays a very important role and might be helpful in terms of sustainable development. The analysis of the $E C o C$ regulations and reports revealed the Programme to still be quite weak in the integration of sustainability aspects overall.

According to Soini and Dessein (2016, p.1): "it is important and necessary to explicitly integrate culture in sustainability discourse, as achieving sustainability goals essentially depends on human accounts, actions, and behaviour which are, in turn, culturally embedded". We argue, therefore, that the $E C o C$ Programme should be shifted from Mode 1 Culture in Sustainability to Mode 3 Culture as Sustainability (as presented in Fig. 1). The decisions and actions of the responsible authorities are of great importance to such a change.

We thus emphasise the necessity of reviewing the aims and objectives of the $E C o C$ 's documents while integrating more linkage to the overall sustainable development. Admitting the power of marketing, the $E C o C$ should clearly interrelate culture and sustainability, providing a coherent marketing strategy (sustainability marketing) grounded on sustainable thinking. The employment of experts and appropriate decision-making support systems in sustainable development would lead to the achievement of this goal; while the inclusion of joint culture - sustainability marketing means as the assessment criteria for the determination of the winners of the $E C o C$ title could be worth discussing further.

\section{Conclusions}

It has already been proven that sustainability as a common global idea should be integrated in both individual and societal beliefs, values and behaviours. Culture, being perceived as a set of shared beliefs, values and expected behaviours, could then become a key element in empowering people with the new understanding of the common world and its problems, or with the impetus to focus on sustainability in other words.

The proper integration of cultural policy into the overall development of the social system may impact and change cultural values and beliefs, shifting them towards sustainability and sustainable behaviour. The ideal result of this shift would shape or reshape the meaning of the natural environment, considering it a constituent of culture, and would lead to completely new policies accommodating sustainability principles as well. This shift could also raise new modes of self-governance or even meta-governance.

Political decisions and actions are mostly important for sustainability and sustainable development. Regional and local strategies should include policies which involve and engage citizens into collective or individual sustainable actions and lead to sustainable behaviour or even transformation into a sustainable society living within sustainable self-governance.

Improving sustainability in the appropriate territory is possible while serving as the European Capital of Culture. The ECoC Programme may play an important role while shifting to the new mode of development. The marketing of the Programme is described as a comprehensive action.

Marketing should be oriented to the entire community, its social goals and the protection of the environment, and should both include all sustainability aspects and be promoted by using various means of marketing.

Sustainability marketing is therefore of great impor- 
tance from both the initiating and implementing sides of the Programme. Sustainable marketing, not just sustainability alone, should be considered as prerequisites for the selection criteria while competing for the $E C o C$ title and the future ex-post evaluation of the impact and effects of the ECoC. Decision-making support systems might help both politicians and experts improve the ECoC programme's impact on the transformation to sustainability.

\section{Literature}

Aubert, A., Marton, G., \& Raffay, Z. (2015). Impacts of the European capital of culture title of Pécs on the city's tourism. Geographica Timisiensis, 24(1), 31-42.

Bell, S. \& Morse, S. (2003). Measuring Sustainability: Learning by Doing. Earthscan Publications Ltd.

Belz, F.M. \& Karstens, B. (2005). Strategic and Instrumental Sustainability Marketing in the Western European Food Processing Industry: Conceptual Framework and Hypothesis. Proceedings of the Corporate Responsibility Research Conference, Euromed Management School Marseille France, 4. Available from http://www.crrconference. org/Previous_conferences/downloads/belz.pdf

Bohanec, M. (2015). DEXi: Program for Multi-Attribute Decision Making. User's Manual. Versio 5.00. Institut "Jožef Stefan", Ljubljana, Slovenia. Available from http:// kt.ijs.si/MarkoBohanec/pub/DEXiManual500.pdf

Boland, P. (2010). 'Capital of Culture - you must be having a laugh!' Challenging the official rhetoric of Liverpool as the 2008 European cultural capital. Social \& Cultural Geography, 11(7), 627-645, http://dx.doi.org/10.108 0/14649365.2010.508562

Chiu, C.Y., Gelfand, M. J., Yamagishi, T., Shteynberg, G. \& Wan, C. (2010). Intersubjective Culture: The Role of Intersubjective Perceptions in Cross-Cultural Research. Perspectives on Psychological Science, 5(4), 482-493, https://doi.org/10.1177/1745691610375562

Commission staff working document. (2012). European Capitals of Culture post 2019 Accompanying the Document Proposal for a Decision of the European Parliament and of the Council establishing a Union action for the European Capitals of Culture for the years 2020 to 2033. Brussels, 20.7.2012 SWD 226 final. Available from: http:// eur-lex.europa.eu/legal-content/EN/TXT/PDF/?uri=CELEX:52012SC0226\&from $=\mathrm{EN}$

Dessein, J., Soini, K., Fairclough, G. \& Horlings, L. (eds) (2015). Culture in, for and as Sustainable Development. Conclusions from the COST Action IS1007 Investigating Cultural Sustainability. University of Jyväskylä, Finland.

Draghici, C. et al. (2015). The Role of European Capital of Culture Status in Structuring Economic Profile of Sibiu, Romania. Procedia Economics and Finance, 26, 785-791, http://dx.doi.org/10.1016/S2212-5671(15)00870-9

Edwards, M.G. (2009). An integrative metatheory for organizational learning and sustainability in turbulent times. The learning organization, 16(3), 189-207, https:// doi.org/10.1108/09696470910949926

Epstein, M.J. (2008). Making sustainability work: best practices in managing and measuring corporate social, environmental and economic impacts. Greenleaf Publishing.

Eroĝlu, O. \& Piçak, M. (2011). Entrepreneurship, National Culture and Turkey. International Journal of Business and Social Science, 2(16), 146-15.

European Commission. (2014). European Capitals of Culture 2020-2033. Guide for cities preparing to bid.

Fithian, C. \& Powell, A. (2009). Cultural Aspects of Sustainable Development. Available from: http://webmail. seedengr.com/Cultural $\% 20$ Aspects $\% 20$ of $\% 20$ Sustainable\%20Development.pdf

Garcia, B. \& Cox, T. (2013). European capitals of culture: success strategies and long-term effects study. EU Directorate general for internal policies policy department b: structural and cohesion policies culture and education.

Giltrow, M. (2015). Investigating the Relationship of Wellbeing with Sustainable Values, Attitudes and Behaviour. In W.L. Filho (ed.), Transformative Approaches to Sustainable Development at Universities. Springer International Publishing.

Glaeser, E. L., Kolko, J., \& Saiz, A. (2001). Consumer city. Journal of Economic Geography, 1(1), 27-50, https:// doi.org/10.1093/jeg/1.1.27

Golob, A., Lesjak, M., Fabjan, D., Jakulin, T. J. \& Stamenković, I. (2015). Assessment of Sustainability of Sports Events (Slovenia). Turizam, 19(2), 71-83, http:// dx.doi.org/10.5937/Turizam1502071G

Greblikaite, J., Sroka, W., Daugèlienè, R., \& Kurowska-Pysz, J. (2016). Cultural Integration and Cross-cultural Management Challenges in the Central European Countries: Lithuania and Poland. European Integration Studies, (10), 29-43, http://dx.doi.org/10.5755/j01.eis.0.10.16281

Griffiths, R. (2006). City/culture discourses: Evidence from the competition to select the European Capital of Culture 2008. European Planning Studies, 14(4), 415-430, https://doi.org/10.1080/09654310500421048

Hawkes, J. (2001). The Fourth Pillar of Sustainability: Culture's essential role in public planning. Common Ground Publishing \& Cultural Development Network (Vic), Melbourne.

Herrero, L. C., Sanz, J. Á., Devesa, M., Bedate, A., \& Del Barrio, M. J. (2006). The economic impact of cultural events: a case-study of Salamanca 2002, European Capital of Culture. European urban and regional studies, 13(1), 41-57, https://doi.org/10.1177/0969776406058946

Hudec, O., \& Džupka, P. (2016). Culture-led regeneration through the young generation: Košice as the European Capital of Culture. European Urban and Regional Studies, 23(3), 531-538, https://doi. org/10.1177/0969776414528724 
Immler, N.L. \& Sakkers, H. (2014). (Re)Programming Europe: European Capitals of Culture: rethinking the role of culture. Journal of European Studies, 44(1), 3- 29, https://doi.org/10.1177/0047244113515567

Kaunas city municipality (2016). Kaunas European Capital of Culture (pre - final bid). Available from: http://kaunas2022.eu/wp-content/uploads/2017/03/ Kaunas_2022_ECoC_final_bid_EN.pdf

Klaipeda city municipality (2016). Klaipeda European Capital of Culture 2020 (pre - final bid). Available from: https://lrkm.lrv.lt/uploads/lrkm/documents/files/ Klaip\%C4\%97da_2022_ECoC-pre-selection_bid(1).pdf

Lamza-Maronić, M., Glavaš, J. \& Mavrin, I. (2011). Marketing Aspects of the European Capital of Culture Programme. Interdisciplinary Management Research, 7, 130-140.

Lim, W. M. (2016). Lim, W. M. (2016). A blueprint for sustainability marketing. Marketing theory, 16(2), 232249, https://doi.org/10.1177/1470593115609796

Maraña, M. (2010). Culture and Development. Evolution and Prospects. Bilbao, Spain, UNESCO Etxea (UNESCO Etxea Working Papers, No. 1).

Milton Keynes Council (2015). Bidding for Cultural Status. Feasibility Study. Available from: https://www. milton-keynes.gov.uk/assets/attach/28775/MK\%20Capital $\% 20$ of $\% 20$ Culture $\% 20$ Report.pdf

Nechita, F. (2015). Bidding for the European Capital of Culture: Common Strengths and Weaknesses at the Pre-selection Stage. Bulletin of the Transilvania University of Brasov. Series VII: Social Sciences, Law, 8(1).

Nemeth, A. (2010). Mega-events, their sustainability and potential impact on spatial development: the European Capital of Culture. The International Journal of Interdisciplinary Social Sciences, 5, 265-278.

Nkamnebe, A. D. (2011). Sustainability marketing in the emerging markets: imperatives, challenges, and agenda setting. International Journal of Emerging Markets, 6(3), 217 - 232, https://doi.org/10.1108/17468801111144058

Nurse, K. (2006). Culture as the Fourth Pillar of Sustainable Development. Small States: economic review and basic statistics, 1, 28-40.

O'Callaghan, C. (2012). Urban anxieties and creative tensions in the European Capital of Culture 2005: 'It couldn't just be about Cork, like'. International journal of cultural policy, 18 (2),185-204, https://doi.org/10.1080/10 286632.2011.567331

Opuku, A. (2015). The Role of Culture in a Sustainable Built Environment. In A. Chiarini (Ed.), Sustainable Operations Management. Springer International Publishing, 37-52.

Palmer/Rae Associates (2004). European Cities and Capitals of Culture. Brussels: Palmer/Rae.

Peattie, K. \& Belz, FM. (2010). Sustainability marketing - An innovative conception of marketing. Marketing Review St.Gallen, 27(5), 8-15, https://doi.org/10.1007/ s11621-010-0085-7

Peter, C. \& Swilling, M. (2014). Linking Complexity and Sustainability Theories: Implications for Modeling Sustainability Transitions. Sustainability, 6(3), 15941622, http://dx.doi.org/10.3390/su6031594

Pykett, J., Jones, R., Welsh, M. \& Whitehead, M. (2014). The art of choosing and the politics of social marketing. Policy Studies, 35(2), 97-114, https://doi.org/10.1 080/01442872.2013.875141

Rakic, B. \& Rakic, M. (2015). Holistic management of marketing sustainability in the process of sustainable development. Environmental Engineering and Management Journal, 14(4), 887-900. Available from: http://omicron. ch.tuiasi.ro/EEMJ/

Richards, G. (2000). The European Cultural Capital Event: Strategic Weapon in the Cultural Arms Race? Journal of Cultural Policy, 6(2), 159-181, https://doi. org/10.1080/10286630009358119

Rindzevičiūtè, E., Svensson, J. \& Tomson, K. (2016). The international transfer of creative industries as a policy idea. International Journal of Cultural Policy, 22(4), 594610, https://doi.org/10.1080/10286632.2015.1025067

Sazonova, L. (2014). Cultural Aspects of Sustainable Development: Glimpses of the Ladies' Market. FriedrichEbert-Stiftung, Office Bulgaria.

Scammon, D. (2012). Sustainability and culture: how do they work together? LCC 480 senior seminars, 30 April 2012. Available from: http://www.academia.edu/1817961/ Sustainability_and_Culture_How_do_they_work_together [cited from A. Chiarini (ed.), Sustainable Operations Management. Springer International Publishing]

Selection of the European Capital of Culture for the year 2022 in Lithuania. (2016). The Selection Panel's report. Pre-Selection Stage. Vilnius. Available from: https:// ec.europa.eu/programmes/creative-europe/sites/creative-europe/files/files/ecoc-2022-lithuania-preselection. pdf

Senge, P. \& Smith, B. (2008). The necessary revolution: how individuals and organizations are working together to create a sustainable world. USA.

Senkus, P. (2013). Marketing 3.0: The Challenge for Private, Public and Non-profit Sectors, Theoretical Approach. Rural Development. The sixth International Scientific Conference, Proceedings, 6, 328-335.

Slaper, T. F. \& Hall, T. J. (2011). The Triple Bottom Line: What Is It and How Does It Work? Available from: http://www.ibrc.indiana.edu/ibr/2011/spring/article2.html

Soini, K. \& Dessein, J. (2016). Culture-Sustainability Relation: Towards a Conceptual Framework. Sustainability, 8(2), 167, http://dx.doi.org/10.3390/su8020167

Sridhar, K. \& Jones, G. (2013). The three fundamental criticisms of the Triple Bottom Line approach: An empirical study to link sustainability reports in companies based in the Asia-Pacific region and TBL shortcomings. Asian Journal of Business Ethics, 2(1), 91-111. 
Steiner, L., Frey, B., \& Hotz, S. (2015). European capitals of culture and life satisfaction. Urban studies, 52(2), 374-394, http://dx.doi.org/10.1177/0042098014524609

Thaler J. \& Helmig B. (2013). Theoretical Framework of Social Marketing Effectiveness: Drawing the Big Picture on its Functioning. Journal of Nonprofit \& Public-Sector Marketing, 25, 211-236, https://doi.org/10.108 0/10495142.2013.819708

Turşie, C. (2015). Re-Inventing the Centre-periphery Relation by the European Capitals of Culture. Case-studies: Marseille-Provence 2013 and Pecs 2010. Eurolimes, 19.

Wróblewski, Ł. (2016). Creating an Image of a Region-Euroregion Beskydy and Euroregion Cieszyn Silesia examples. Ekonomia i Zarzadzanie, 8(1), 91-100, https:// doi.org/10.1515/emj-2016-0010

Van Aalst, I. \& van Melik, R. (2012). City festivals and urban development: does place matter? European Urban and Regional Studies, 19(2), 195-206, https://doi. org/10.1177/0969776411428746
Valentina Burksiene received her Master's degree in Management of Recreation and Tourism from Klaipeda University, Klaipeda, Lithuania in 2006. She received her $\mathrm{PhD}$ in Management and Administration (Social Sciences) from Kaunas University of Technology in 2012. Since 2016, she has been an Associate Professor at the Department of Public Administration and Social Geography of Social Science Faculty, Klaipeda University. Her areas of research include sustainable development, strategic planning, organizational learning, public administration and tourism management.

Jaroslav Dvorak is associate professor and head of the Department of Public Administration and Social Geography at Klaipeda University in Lithuania. He was visiting researcher at Uppsala University in Sweden, Institute of Russian and Eurasian studies. His work focuses on evaluation capacity building in public administration, public service delivery models and alternatives, prevention of frauds in local governments, administration of industrial relations.

Gabriele Burbulyte-Tsiskarishvili received $M A$ in Public Administration at Klaipeda University (Klaipeda, Lithuania) in 2002. She works as lecturer at the Department of Public Administration and Social Geography at Klaipeda University since 2002. Areas of research include regional policy, local governance, and management of organizations. 